DOI 10.11603/2414-4533.2016.4.7201

\title{
Вінок спогадів про Хірурга та Вчителя
}

\author{
Щоби хірургія стала дисципліною інтелекту, \\ саме фізіологічні концепції мають бути засвоєні \\ хірургами та зайняти в їх роботі більш важливе місце, \\ аніж технічна сторона проблеми.
}

Рене Фонтен, президент 23-го конгресу хірургів, Буенос-Айрес, 1956 p.

\begin{abstract}
Нестримно плине час. Минають десятиліття та століття... Проте велич звершень славетних людей залишається незатьмареною плином часу. Особливо це стосується тих, хто причетний до фундаментальних речей, котрі служать основою і дороговказом у лікуванні хворих та сприяють швидкому одужанню, особливо тяжких хірургічних хворих.

30 січня 2017 р. виповнюється 100 років із дня народження одного зі знаних серед плеяди львівських хірургів у царині сепсисології та хірургічної гастроентерології доктора медичних наук, професора хірургії
\end{abstract} Григорія Артемовича Івашкевича.

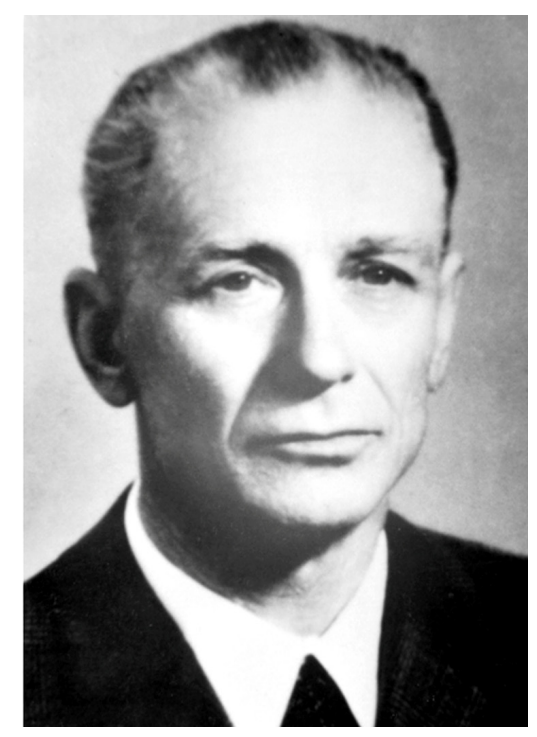

блем лікування хворих принесли йому славу хірурга, що поширилася за межі вказаних регіонів. Його робочий день був не обмеженим у часі, якщо цього вимагали обставини.

Саме працюючи в районних лікарнях, молодий хірург продовжив узагальнювати свій фаховий досвід, набутий під час війни. Так, він вдосконалював методики герніопластики, лікування ургентної хірургічної патології і травмованих хворих.

Кандидатська дисертація Григорія Артемовича була присвячена діагностичному значенню пульсації черевного відділу аорти при гострих захворюваннях органів че-

Спробуємо згадати його життєвий шлях та внесок у медичну науку й практику.

Народився в далекому 1917 р. в невеликому містечку Юстиноград, що на Київщині. Так склалося, що згодом батьки переїхали на Донбас, де тривали його дитячі роки. Рано залишившись без опіки батьків, змушений був іти навчатись у ремісниче училище. Після закінчення була робота на шахтах Донбасу. Ймовірно, тут, ще молодим, Григорій Артемович відчув труднощі життя та його ціну, що й сформувало його подальший життєвий світогляд.

Вступив до Харківського медичного інституту, на старших курсах перевівся у Військово-медичну академію ім. С. М. Кірова в Ленінграді, яку успішно закінчив.

Так склалося, що початок лікарської кар’єри майбутнього видатного хірурга збігся з початком Великої Вітчизняної війни. Був фронт, робота хірургом польового госпіталю. Саме цей період життя молодого лікаря Григорія Івашкевича визначив його подальший фаховий напрям - хірургію.

Після завершення війни він опиняється в Західній Україні. Спочатку працює хірургом у Великих Мостах, а далі - завідування хірургічним відділенням у Яворові, відтак - у Жовкві (Несторів) на Львівщині.

Ентузіазм, працелюбність Григорія Артемовича, невтомний пошук у вирішенні ряду питань і про- ревної порожнини. Слід зазначити, що цю наукову роботу він виконав, працюючи районним хірургом.

Успішний захист кандидатської дисертації сприяв отриманню за конкурсом посади доцента кафедри туберкульозу Львівського медичного інституту в 1956 р. Одночасно він обіймає посаду завідувача відділення торакальної хірургії. Тут проявляються його енциклопедичні знання та поліхірургічна практика. Він широко застосовує термокаутер для лікування хворих на туберкульоз легень. Цей метод може бути прообразом сучасної малоінвазивної хірургії.

У подальшому були робота на кафедрі загальної хірургії та наукова діяльність під керівництвом професора Г. П. Ковтуновича - вихідця Ленінградської онкохірургічної школи професорів М. М. Петрова і М. І. Напалкова.

У цей час молодий ще доцент Г. А. Івашкевич вивчає перебіг та лікування правця. Дане захворювання було поширене в Західній Україні - арені Першої світової війни, де важливе місце посідали кавалерія з кіннотою.

У 1967 р. Григорій Артемович успішно захистив докторську дисертацію, в якій відтворено комплексне лікування правця і запропоновано транспортування хворих на правець до Львова із зосередженням їх в єдиному центрі, що переріс у Центр лікування хірургічного сепсису. 
Слід зазначити, що значна частина дисертації, як і подальша наукова робота знаного хірурга та його учнів, грунтувалися на даних, отриманих в експерименті на лабораторних тваринах із подальшим перенесенням цих даних у клінічну практику.

У 1965 р. Г. А. Івашкевич очолив кафедру хірургії, котра в подальшому отримала назву шпитальної хірургії; керував нею до 1987 р. Його клініка розміщувалася на базі першого хірургічного відділення Львівської обласної клінічної лікарні. Він розробляв і широко впроваджував фізіологічні методи операційного лікування. Це стосується, перш за все, резекції шлунка за Більрот I із формуванням терміно-латерального анастомозу однорядним кишковим швом. Окрім цього, запропонував метод консервативного лікування кровотечі 3 виразки дванадцятипалої кишки із застосуванням інгібіторів протеолізу та хірургічного лікування ускладненої діабетичної стопи.

У своїй клініці Григорій Артемович концентрував контингент особливо тяжких хворих із хірургічним сепсисом, перитонітом і кишковими норицями.

Ніколи не полишав теми гнійної хірургії та сепсису. Так, його кафедра прискіпливо вивчала біохімічні і патофізіологічні процеси у хворих на сепсис та перитоніт як у клініці, так і в експерименті на лабораторних тваринах.

Професор Григорій Артемович Івашкевич створив свою наукову школу. Вона невелика, лишень дев’ять кандидатів наук. Втім, кожне дисертаційне дослідження фундаментальне, обгрунтоване, виконане на високому рівні і несе в собі наукову новизну. Зокрема, вивчення калікреїн-кінінової системи, системи протеолізу і неферментних катіонних білків при сепсисі і гострих шлунково-кишкових кровотечах.

Необхідно відзначити, що науковий пошук лише одна грань життя великої Людини.

Григорій Артемович виховав цілу плеяду клінічних ординаторів, які навчалися в нього на кафедрі, а в подальшому очолили хірургічні служби в районах. Всіх ординаторів свого першого хірургічного відділення Львівської обласної клінічної лікарні, що працювали поряд з ним, він навчив виконувати складні операційні втручання, такі як геміколектомія і резекція шлунка за Більрот I із терміно-латеральним однорядним кишковим швом. Він щиро ділився своїм фаховим досвідом і передавав його колегам та співробітникам.

Не можна оминути високу хірургічну техніку професора, котру відзначали не тільки хірурги Львова, України, СРСР, але й за кордоном.

Найбільше вражають в особистості професора Г. А. Івашкевича його інтелігентність та внутрішня культура i, передусім, людяність. Він однаково ставився як до пацієнтів із львівського бомонду, так і до простих селян із Яворівщини, які приїжджали до нього оперуватись.

Інтелігентність проявлялась у ставленні до колег-лікарів з інших клінік. Григорій Артемович ніколи не відмовляв у будь-який час допомогти молодим колегам виконати складні втручання, якщо цього потребували обставини, навіть будучи в похилому віці, понад 70 років, коли працював у Дрогобицькому вільному медичному інституті ім. Ю. Котермака в 90-х роках ХХ століття.

Слід відзначити і його всебічний розвиток. Так, перебуваючи на симпозіумах та конгресах у різних містах Радянського Союзу, він ніколи не пропускав перегляду вистав чи слухання опери. Систематично відвідував і вистави у львівських театрах. Про це свідчить написана ним на високому фаховому рівні низка відгуків на прослухані опери чи переглянуті вистави.

Професор Г. А. Івашкевич старався завжди допомогти людям: чи то тяжкохворим, які потребували операційних втручань, чи колегам по роботі, що потребували консультацій, чи лікарям-початківцям або студентам-медикам.

Професор Г. А. Івашкевич пішов із життя у 1997 p.

Нехай дане писання про цю велику Людину, Хірурга, Вчителя ляже вінком спогадів на його могилу на Личаківському цвинтарі, що у Львові.

Олег Богданович Прийма - лікар-ординатор урологічного відділення КП “Трускавецька міська лікарня”, доцент кафедри анатомії, фізіології та валеології Дрогобицького державного педагогічного університету імені Івана Франка, кандидат медичних наук, доцент, член НТШ, член УЛТ 